\title{
Redakteursnota
}

Die debat oor politieke, regsfilosofiese en gemeenskapsaspekte van die moderne staat word in hierdie rubriek voortgesit.

In die Junie 2016-nommer van die Tydskrif vir Geesteswetenskappe het Andries Raath, in 'n diskoers met Danie Goosen en Koos Malan, die politieke en regsfilosofiese implikasies van politieke kommunitarisme van nader bekyk.

In die September 2016-nommer tree Danie Strauss toe tot die debat deur aan te voer dat die tekortkominge van sowel individualistiese (atomistiese) as universalistiese (holistiese) benaderings ondervang kan word "indien erns gemaak word met die ontiese beginsels van soewereiniteit-in-eie-kring en universaliteit-in-eie-kring".

In hierdie uitgawe lewer sowel Danie Goosen as Koos Malan repliek op die vorige twee standpunte, soos verwoord deur Andries Raath (Junie 2016) en Danie Strauss (September 2016) onderskeidelik.

Alle lesers van die Tydskrif vir Geesteswetenskappe word weer eens hartlik uitgenooi om deel te neem aan die debat. Beperk u debatsbydraes tot hoogstens 2000 woorde. Indien u sou verkies om liewer uitvoeriger by wyse van 'n navorsingsartikel te reageer, sal dergelike bydraes aan die gewone keuringsprosedure onderhewig wees.

\section{INA WOLFAARDT-GRÄBE}

Oktober 2016 